\title{
TRANSLATION FEATURES OF THE PESHITTA EPISTLE OF JAMES*
}

DOI: http://dx.doi.org/10.12775/TiCz.2019.046

\begin{abstract}
Abstrakt. While much has been written about the the nature of the Old Testament Peshitta vis-à-vis its Vorlage, little work has been done regarding the New Testament Peshitta as a translation. This study will examine the Peshitta Epistle of James as a translation. At the outset, renderings that reflect Greek textual variants will be identified since they do not reflect translation technique. Careful examination of the Syriac text in relation to its Vorlage reveals translation features that characterize this book. The evidence assembled here points to a reader oriented translation. The translator, while being faithful to the Greek, transformed the text into idiomatic Syriac.
\end{abstract}

Keywords: Epistle of James; translation technique; New Testament Peshitta; Syrian language; textual criticism of the New Testament; translation theory.

Streszczenie. Peszitta - List Jakuba. Charakterystyka thumaczenia. Znajdujemy wiele opracowań dotyczących tłumaczenia Starego Testamentu w wersji Peszitta, niewiele zaś jest pozycji dotyczących tłumaczenia Nowego Testamentu w tejże wersji. Niniejsze studium pokazuje translatorski warsztat dotyczący tłumaczenia Listu

* The substance of this essay was presented at V International Biblical Conference "The Bible in Translation" held at Forum Synogoga in Ostrów Wielkopolski under the auspices of the University of Wrocław, 14 May 2018. I would like to thank Dr. Miroslaw Rucki and Dr. Michael Abdalla for their feedback which led to this printed version. 
Jakuba. Na początku, tłumaczenia odzwierciedlające greckie warianty tekstu, będą pokazane bez odniesienia do techniki translacyjnej. Następnie wskażemy charakterystyczne cechy tłumaczonej księgi, by ukazać technikę thumaczenia. Tłumacz, będąc wiernym tekstowi greckiemu, dokonuje transformacji tekstu za pomocą syryjskich idiomów.

Slowa kluczowe: List Jakuba; technika translacyjna; Peszitta Nowy Testament; język syryjski; krytycyzm tekstualny Nowego Testamentu; teoria translacji.

While much has been written about the the nature of the Old Testament Peshitta vis-à-vis its Vorlage, ${ }^{1}$ little work has been done regarding the New Testament Peshitta as a translation. ${ }^{2}$ This study will examine the Peshitta Epistle of James as a translation. At the outset, one must sort out translation features from Greek textual variants. Only then can one examine the translation features and characterize the translation as a translation. Fortunately, the modern editio maior of the Greek New Testament ${ }^{3}$ incorporates the critical edition of the Syriac Peshitta of James

${ }^{1}$ Craig E. Morrison, The Character of the Syriac Version of the First Book of Samuel (Monographs of the Peshițta Institute 11; Leiden: Brill, 2001); Mirko Pozzobon, La Peshitta del Secondo Libro di Samuele (Analecta Biblica 214; Rome: Gregorian \& Biblical Press, 2016); Claudio Balzaretti, The Syriac Versions of Ezra-Nehemiah: Manuscripts and Editions, Translation Technique and Its Use in Textual Criticism (translated by Michael Tait; Biblica et orientalia 51; Rome: Gregorian \& Biblical Press, 2013); Ignacio Carbajosa, The Character of the Syriac Version of Psalms, A Study of Psalms 90-150 in the Peshitta (translated by Paul Stevenson; Monographs of the Peshițta Institute 17; Leiden: Brill, 2008).

${ }^{2}$ Peter J. Williams, Early Syriac Translation Technique and the Textual Criticism of the Greek Gospels (Texts and Studies III, 2; Piscataway: Gorgias Press, 2004).

${ }^{3}$ Novum Testamentum Graecum, Editio Critica Maior, IV: Catholic Letters, Part 1: Text and Part 2: Supplementary Material, edited by The Institute for New Testament Textual Research (2nd Revised Edition; Stuttgart: Deutsche Bibelgesellschaft, 2013). This publication replaces the editio maior of Constantinus Tischendorf (ed.), Novum Testamentum Graece, Vol. 2 (Editio octava critica maior; Leipzig: Giesecke \& Devrient, 1872), 248-272. 
published in 1986. ${ }^{4}$ In addition, Bruce M. Metzger has provided a valuable textual commentary to the Greek text. ${ }^{5}$ Further, the Accordance electronic modules of the Greek New Testament and Peshitta New Testament, based on the twenty-eighth revised edition of Novum Testamentum Graece ${ }^{6}$ and the Peshitta text of the British and Foreign Bible Society ${ }^{7}$ respectively, serve as valuable tools for researching this issue.

With regard to Greek Vorlage, it appears that the translator of the Peshitta used a text that was developed, yet not always the same as the so-

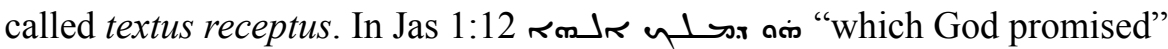

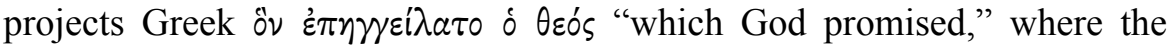
expressed subject $\delta$ Өcós "God" reflects a developed Greek text. Other Greek text witnesses read the expressed subject as $\delta$ xúplos "Lord." The

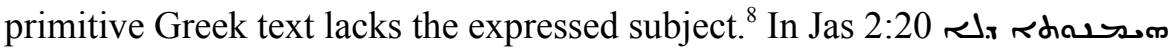

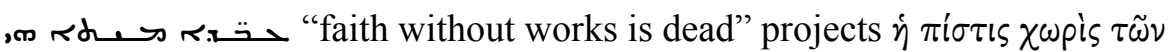

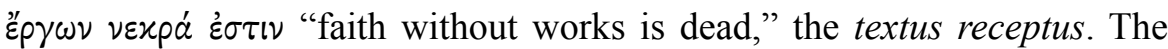

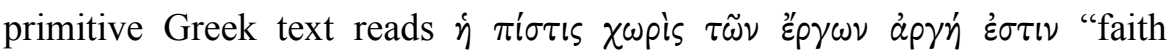
without works is useless." In Jas 2:25 the primitive Greek text reads Rahab the harlot welcomed the áy confusion with the meaning "angels" a substitute entered the Greek textual

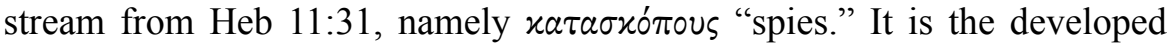

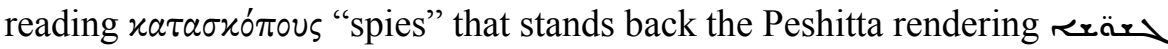

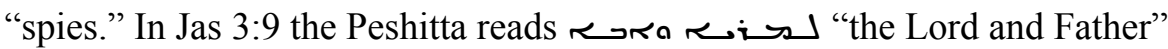

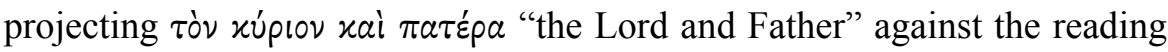

${ }^{4}$ Das Neue Testament in syrischer Überlieferung, I: Die grossen katholischen Briefe, in Verbindung mit A. Juckel, herausgegeben und untersucht von Barbara Aland (ANTT 7; Berlin: de Gruyter, 1986). Citations of the Peshitta in this essay come from this edition.

${ }^{5}$ Bruce M. Metzger, ed., A Textual Commentary on the Greek New Testament (Second edition; Stuttgart: Deutsche Bibelgesellschaft, 1994).

${ }^{6}$ Barbara and Kurt Aland, Johannes Karavidopoulos, Carlo M. Martini, and Bruce M. Metzger, eds., Novum Testamentum Graece (28th revised edition; Stuttgart: Deutsche Bibelgesellschaft, 2012).

${ }^{7}$ The New Testament in Syriac (London: The British and Foreign Bible Society, [1920]).

\footnotetext{
${ }^{8}$ So Metzger, 608.

${ }^{9}$ The replacement reading "dead" derives from Jas 2:17 or 26.
} 


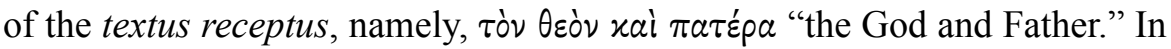
Jas 5:7 until he receives the early rain

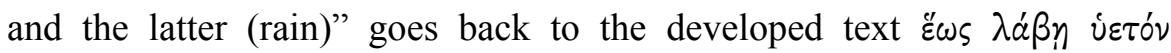

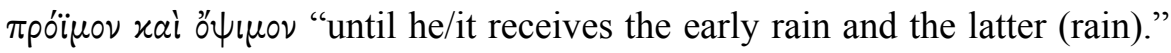

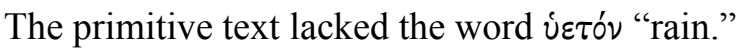

Some cases are not so straightforward. In Jas 4:4 the Peshitta reads

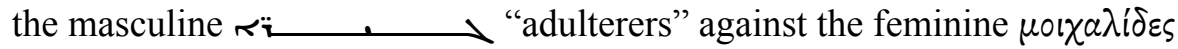

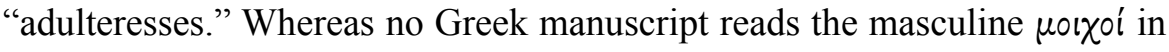

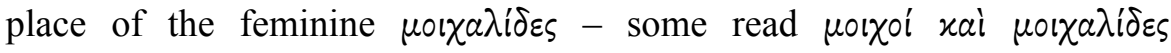
"adulterers and adulteresses" -, the Peshitta's rendering should be regarded as a reflex of feminine $\mu \circ \imath \chi \alpha \lambda i \delta \varepsilon \varsigma .{ }^{10}$ In context, the term certainly includes men. Such a rendering points to the Peshitta of James being reader oriented rather than source text oriented.

Regarding citations of and allusions to the Old Testament, the translator of the Peshitta of James followed his Greek Vorlage rather than inserting the language of the OT Peshitta. Pesh-Jas 2:8, reading _ـ wid "you shall love your neighbor as yourself," follows the

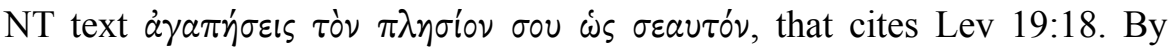

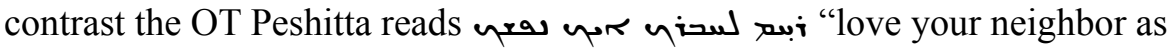
yourself." The prefix conjugation form oـ _uid of Pesh-James reflects the Greek future form á $\gamma \alpha \pi \dot{\eta} \sigma \varepsilon ı$, while the OT Peshitta text has the imperative form. Moreover, the word used for neighbor 3 mirrors the Greek $\pi \lambda \eta \sigma^{\prime}$ ov and is different from the OT word $\kappa_{i}$. Jas 5:4 uses phraseology

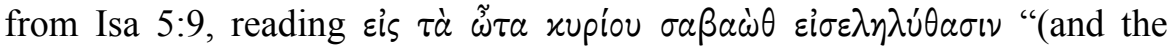
cries of the reapers) have entered the ears of the Lord of Sabaoth." PeshJames reads 1 גars entered into the ears of the Lord Sebaoth," clearly different from the OT Peshitta's בـ "it was heard in the ears of the mighty Lord." In Jas 5:5 the translator rendered the NT text $\dot{\varepsilon} \nu \dot{\eta} \mu \varepsilon \dot{p} \rho$

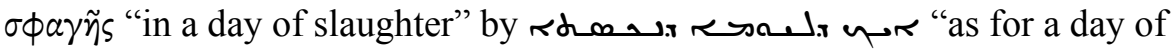
slaughter" using a different lexeme than in Jer 12:3 (لسم م6 "for the day of killing"). Since the Peshitta of James reflects the practice of translating

${ }^{10}$ NRSV renders "Adulterers!" 
the Greek of the New Testament instead of substituting the reading of the Peshitta Old Testament - the strategy found in the Old Syriac Gospel of the distinct evangelists $-{ }^{11}$ it seems reasonable to date the translation of James to the fifth century. ${ }^{12}$

In this study, we will identify some notable translation features of the Peshitta Epistle of James. These will allow us to characterize the translation. How has the translator encoded the Greek in his translation? Is he guided rigidly by the source language or does he allow room for free expression in the target language? The example from Jas 4:4 indicates a reader oriented translation. Further examples will either confirm or modify this finding.

\section{LANGUAGE CODING IN THE TARGET LANGUAGE}

\section{EXPRESSIONS OF THE GENITIVE RELATIONSHIP}

The Peshitta of James renders Greek constructions expressing the genitive relationship between two nouns or a pronoun and a noun into idiomatic Syriac. The simple construct state syntagm is confined to the

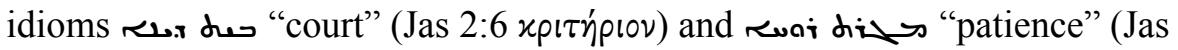

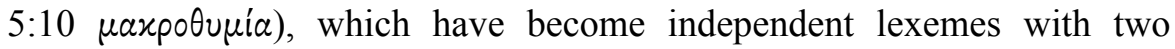
constituents in Syriac. Often, the translator used the syntagm noun in the emphatic state + dalath + noun in the emphatic state as in "risurs "the Father of lights" (Jas 1:17), shros ral "word of truth" (Jas 1:18) - the

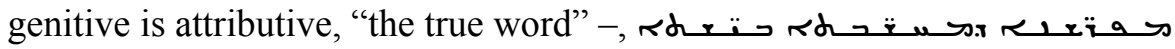

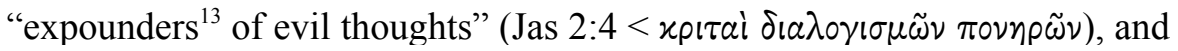

${ }^{11}$ Sebastian Brock, The Bible in the Syriac Tradition (Second Revised Edition; Gorgias Handbooks 7; Piscataway: Gorgias Press, 2006), 33.

12 Brock dates the Peshitta New Testament, which he views as a revision of the Old Syriac, to about 400. Brock believes that there was an Old Syriac translation of Acts and the epistles, though non extant in the Old Syriac form, in addition to the Old Syriac Gospel (Brock, The Bible in the Syriac Tradition, 33).

13 So Michael Sokoloff, A Syriac Lexicon (Winona Lake: Eisenbrauns and Piscataway: Gorgias Press, 2009), 811. 
Rhair "the law of freedom" (Jas 2:12). The Greek adjective is expressed via the construct relationship in Jas 2:15, daily

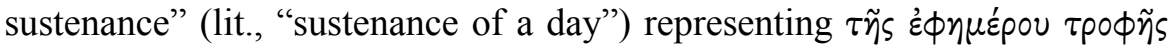
"daily nourishment," in Jas 3:7, لע. של "by the human species" (lit., "by the species of humanity") rendering $\tau \tilde{\eta} \phi \dot{\sigma} \sigma \varepsilon l \tau \tilde{\eta}$ aे $\nu \rho \omega \pi i \nu \eta$ "by the human species," and in Jas 3:8, סـ "a deadly drug" (lit., "a drug

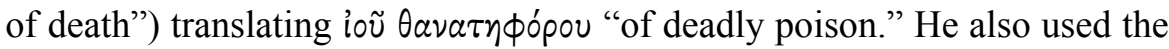
syntagm with the proleptic pronoun on the first noun as in

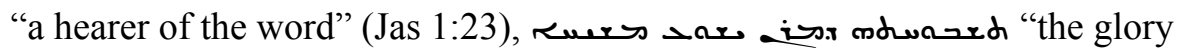
of our Lord Jesus Christ" (Jas 2:1), مس "the need of the body"

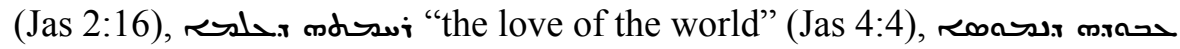
"the doer of the law" (Jas 4:11), אזיـ "the ears of the Lord" (Jas

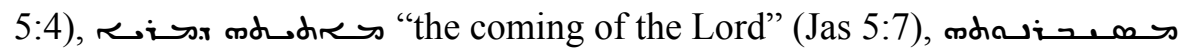

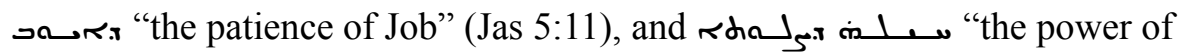
prayer" (Jas 5:16). One should not confuse the anaphoric suffix with the proleptic pronoun in את "someone with his rings of gold"

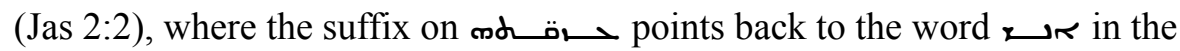
context.

In characteristic Syriac the construct chain can be interrupted by a preposition as in "transgressors of the law" rendering

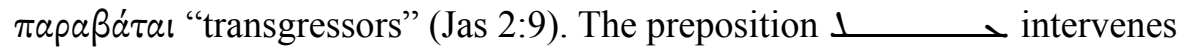
between the nomen regens, حـ , w which is the masculine plural participle in

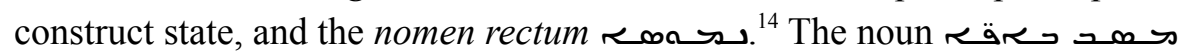

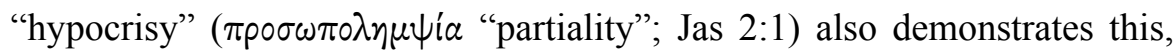
where the first constituent

\section{POSSESSIVE SUFFIXES}

Possessive suffixes are attached directly to the noun, not introduced

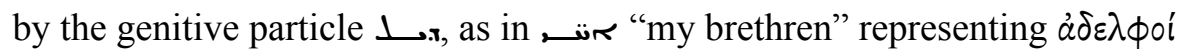

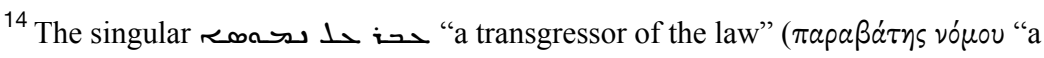
transgressor of the law") appears in Jas 2:11.

15 Theodor Nöldeke, Compendious Syriac Grammar (transl. James A. Crichton; London: Williams \& Norgate, 1904), § 206. 


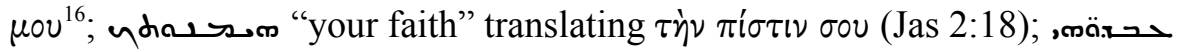

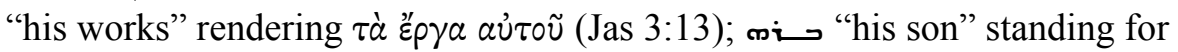

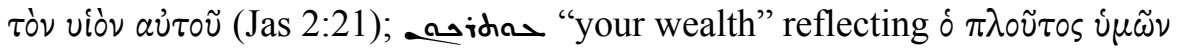

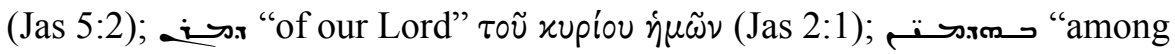

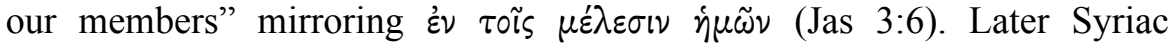
translators of Greek literature regularly used 1 as in brethren" in such cases.

\section{EXPRESSING THE PARTITIVE}

The translator expressed the partitive in good Syriac. ${ }^{17}$ He rendered

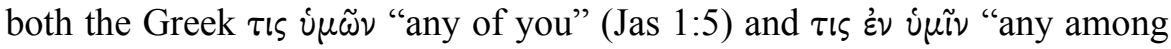
you" (Jas 3:13 and 19) as r. "any of you," using the preposition

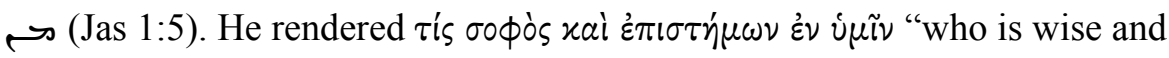
understanding among you" as "Who is it among you that is wise and learned" (Jas 3:13).

\section{WORD ORDER - APPOSITION}

The Syriac translator changed the compact structure of the Greek

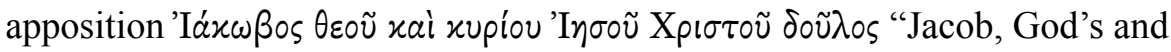
the Lord Jesus Christ's servant," where the appositive comes in final

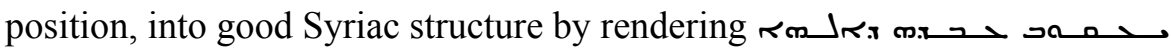
"Jacob, the servant of God and of our Lord Jesus the Messiah," in which the apposition immediately follows the head noun (Jas 1:1). In Syriac the appositive "servant" immediately follows the head noun "Jacob."

${ }^{16}$ Jas $1: 2,16,19 ; 2: 1,5,14 ; 3: 1,10,12 ; 4: 11 ; 5: 7,9,10,12,19$.

${ }^{17}$ Nöldeke, Compendious Syriac Grammar, § 249C, notes that the partitive use of $\rightarrow$ is extensive. 


\section{USE OF THE PRONOUN IN VERBAL RECTION}

Unlike Greek, Syriac frequently uses a redundant pronoun, usually proleptic, as part of the government of the verb. Proleptic pronouns appear

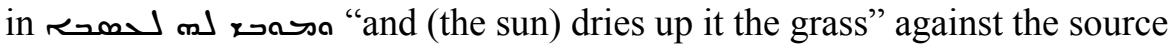

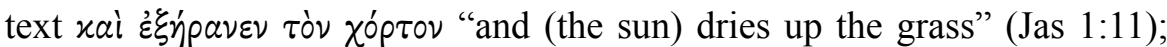
"defiles it our whole body" against the source text $\dot{\eta}$

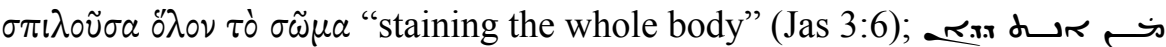
"who are you that you judge him your neighbor" over

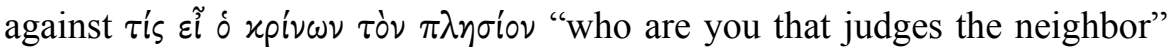
(Jas 4:12); faith will heal him the one that is sick" against xai $\dot{\eta} \varepsilon \dot{u} \times \dot{\eta} \tau \tilde{\eta} s \pi i \sigma \tau \varepsilon \omega \varsigma \sigma \omega \dot{\sigma} \sigma \varepsilon l$

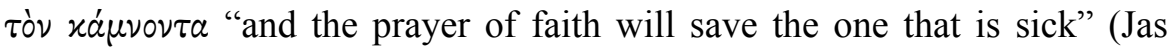

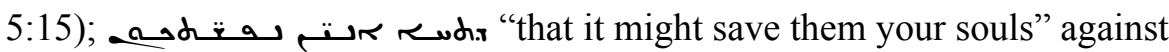
$\sigma \tilde{\omega} \sigma \alpha \iota \tau \dot{\alpha} \varsigma \psi v \chi \dot{\alpha} \varsigma \dot{u} \mu \tilde{\omega} \nu$ "to save your souls" (Jas 1:21).

To express the concept of "have" Syriac uses the preposition lamadh as in but let her patience have

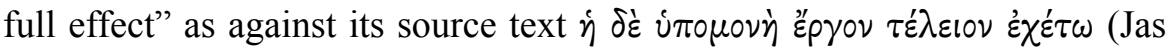

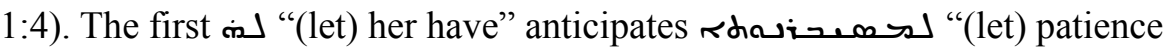
have"; the second in points back to rhorineasl. This is good Syriac.

\section{RENDERINGS OF THE GREEK FUTURE TENSE}

The Syriac translator rendered the Greek future tense (26 cases in 17 verses) with the participle 19 times,${ }^{18}$ with the prefix conjugation 5 times,${ }^{19}$ with the adjective once, ${ }^{20}$ and with the construction 2 (passive participle) + dalath + prefix conjugation once. ${ }^{21}$ This pattern fits the profile of a reader oriented translation.

${ }^{18}$ Jas 1:5, 7, 10, 11, 12; 2:18 (2x); 4:7, 13 (4x), 15 (second case); 5:3 (first case;

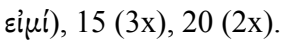

\footnotetext{
${ }^{19}$ Jas 1:25 (Ei $\left.\mu^{\prime}\right) ; 2: 8$ (OT citation); 4:8, 10, 15 (first case).

20 Jas $3: 1$.

${ }^{21}$ Jas 5:3 (second case).
} 


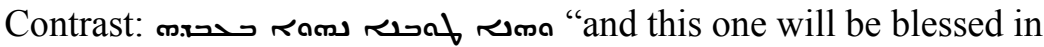

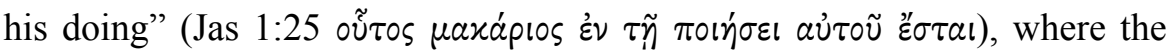
translator used the prefix conjugation, with rhaxm a "and their corrosion will be evidence against you" (Jas 5:3 xail ó iós

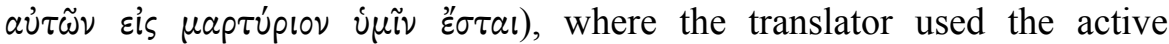
participle.

\section{REFLEXES OF THE GREEK IMPERATIVE}

Negated imperatives are rendered into good Syriac as $\_+$prefix

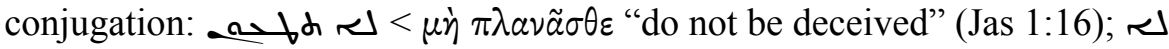

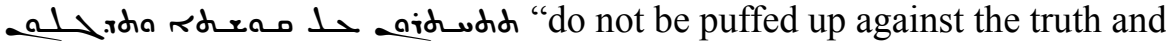

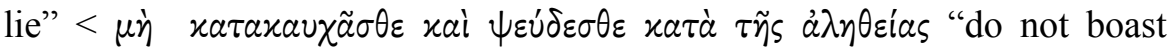
against and be false to the truth" (Jas 3:14);

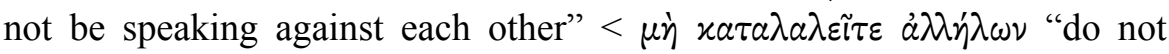
slander one another" (Jas 4:11); سل "do not groan against one another" < $\mu \dot{\eta} \sigma \tau \varepsilon \nu \alpha \dot{\zeta} \varepsilon \tau \tau \varepsilon \ldots \kappa \alpha \tau$ ' $\dot{\alpha} \lambda \lambda \dot{\eta} \lambda \omega \nu$ "do not groan against one another" (Jas 5:9). Once, this Greek syntagm is rendered by $>+$ the periphrastic construction consisting of ram in the suffix conjugation +

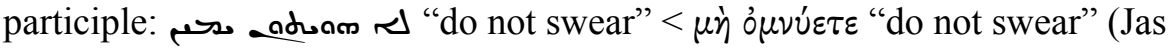
$5: 12$ ). This, too, is idiomatic Syriac. ${ }^{22}$

Positive imperatives are generally rendered by the Syriac imperative form. In two verses, however, the idiomatic construction consisting of ram in the suffix conjugation + participle appears:

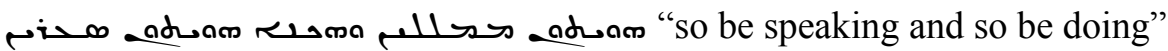

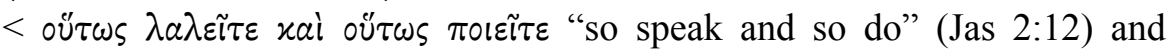
"adund confess your faults one to another and pray one for the other" < $<\dot{\xi} \xi \rho \mu \lambda \circ \gamma \varepsilon \tilde{\sigma} \sigma \theta \varepsilon$ oũ $\nu^{23}$

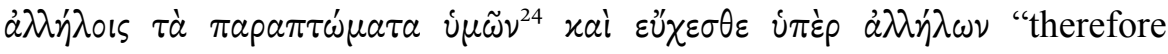

\footnotetext{
${ }^{22}$ Nöldeke, Compendious Syriac Grammar, § 260.

${ }^{23}$ See also Jas 5:7 where r. renders oũv.

${ }^{24}$ The Syriac read $\tau \dot{\alpha} \pi \alpha \rho a \pi \tau \dot{\omega} \mu \alpha \tau \alpha \dot{v} \mu \tilde{\omega} \nu$ "your transgressions" as over against $\tau \dot{\alpha} \varsigma$ áraptías "(your) sins."
} 
confess your transgressions to one another and pray for one another" (Jas $5: 16)$.

The idiomatic construction consisting of ram in the suffix

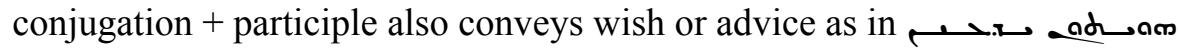

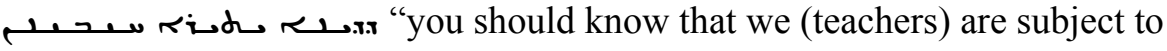
greater judgment" (Jas 3:1). This, too, is good Syriac, conveying the message of the text clearly to the reader in his own vernacular.

\section{RENDERINGS OF THE GREEK INFINITIVE}

The Greek infinitive appears 26 times in James in 20 verses. The translator transferred the Greek infinitive into good Syriac using a variety

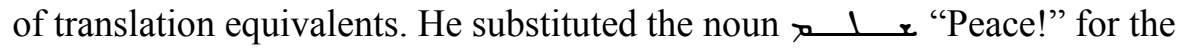

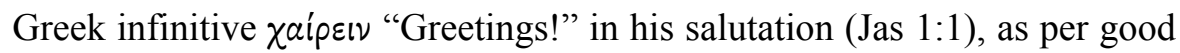
Syriac. ${ }^{25}$ In the purpose clause, he used dalath + the prefix conjugation as

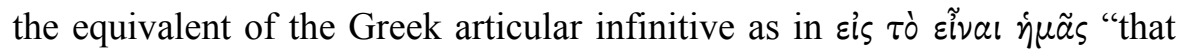
we should be" rendered as ram_. "that we should be" (Jas 1:18). As a complement of the verb "be able" he rendered the Greek infinitive by the conjunction dalath + prefix conjugation as in "the word implanted in your nature, which is

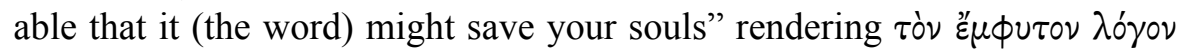

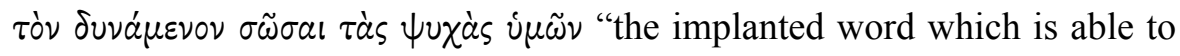
save your souls" (Jas 1:21) and "who is able that he

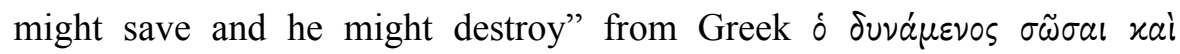
$\dot{\alpha} \pi 0 \lambda \varepsilon \dot{\sigma} \sigma a l$ "who is able to save and to destroy" (Jas 4:12) in accordance with Syriac idiom. He used a "that" clause containing the participle to convey

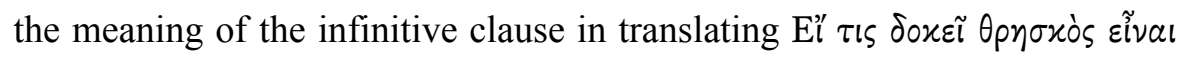

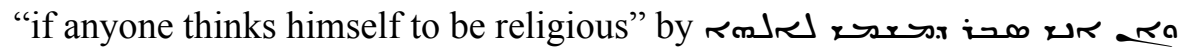
"and if anyone thinks that he serves God" translates (Jas 1:26). Yet, he retains the infinitive when used as a complement of a participle functioning

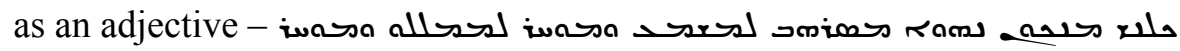

${ }^{25}$ For the Greek infinitive as a greeting in letters, see Acts 15:23 (the letter of the apostles and elders to the Gentile believers) and Acts 23:26 (the letter of Claudius Lysias to Felix). In both places the Syriac translator rendered it by the noun علم "Peace!" as here. 
$\Delta$ "let every one of you be eager to hear and slow to speak and slow to

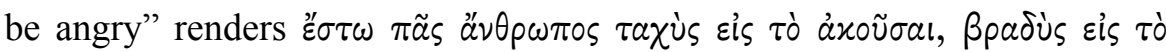

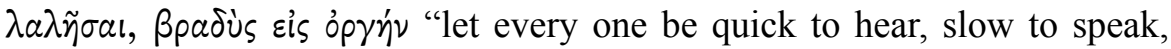
slow to anger" (Jas 1:19) -, when the infinitive phrase functions as a

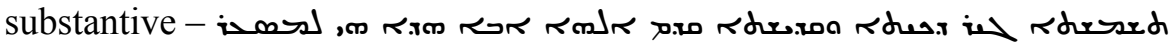
"For pure and holy service before God the Father is this: to visit the fatherless and widows in their afflictions and to keep oneself from the world without

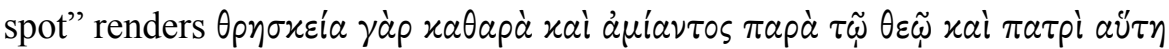

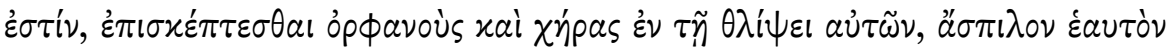

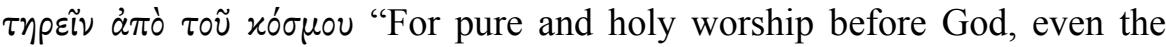
Father, is this: to visit the orphaned and the widows in their affliction, to keep oneself spotless from the world" (Jas 1:27) -, and when he uses the Syriac syntagm with רג to express the future "like people who you are to be judged by

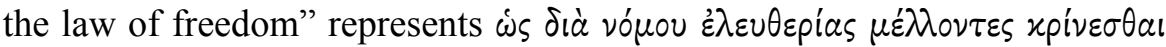
"like those who are to be judged by the law of liberty" (Jas 2:12). In citing the well known verse Gen 15:6, Pesh-James uses "Abraham" like the Greek-"and Abraham believed God and it was reckoned to him as righteousness"-, while the OT text reads "Abram."

\section{RENDERING OF THE GREEK PARTICIPLE EXPRESSING ATTENDANT CIRCUMSTANCES}

Often where the Greek participle expresses attendant circumstance, being subordinate to the main verb, the Peshitta renders it via coordination

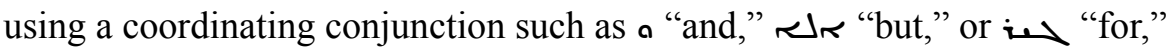
instead of subordination. In Jas 1:14, the translation coordinates the verbal elements with conjunctive waw:

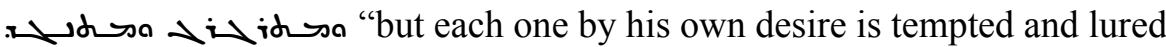

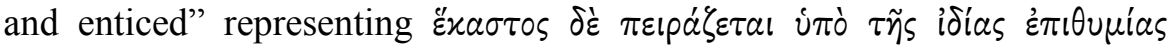

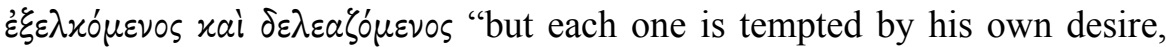
being lured and enticed." The same happens in Jas 1:22, where the participle becomes an imperative due to coordination: "Be doers of the word and not hearers only and do not deceive yourselves" renders $\Gamma^{\prime} \nu \varepsilon \sigma \theta \varepsilon \delta \varepsilon \dot{\varepsilon} \pi \circ \eta \eta \tau \alpha i$ 


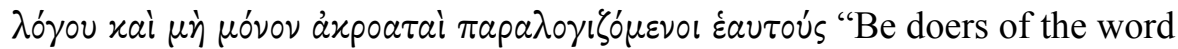

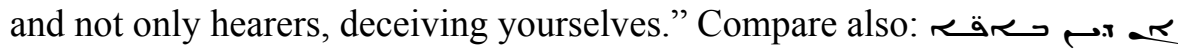

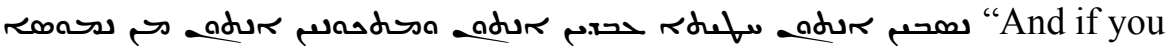
show favoritism you commit sin and you are reproved by the law" for $\varepsilon \dot{l} \delta \dot{\varepsilon}$

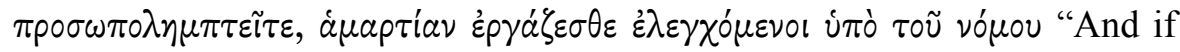
you show favoritism you commit sin, being exposed by the law" (Jas 2:9);

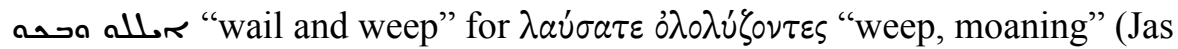

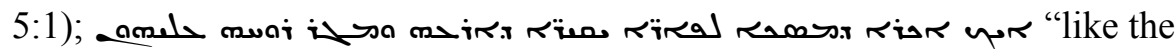
farmer who waits for the precious fruits of his land and is patient for them"

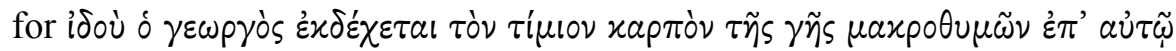
"Behold the farmer waits for the precious fruit of the land, being patient for

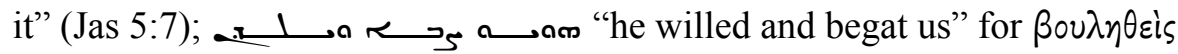

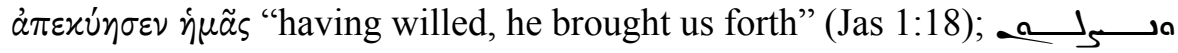
"and they should pray for him and anoint him with

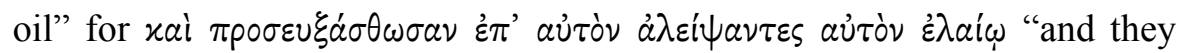
should pray for him, having anointed him with oil" (Jas 5:14).

The translator added $\underset{2}{\longrightarrow}$ as the coordinating conjunction in Jas

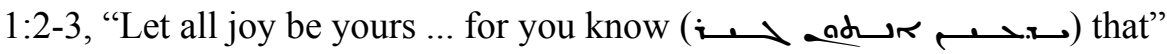
representing "Count it all joy ..., knowing ( $\gamma(v \omega ́ \sigma \kappa o v \tau \varepsilon \varsigma)$ that." Moreover,

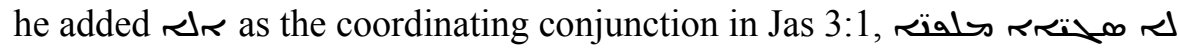
"There should not be many teachers

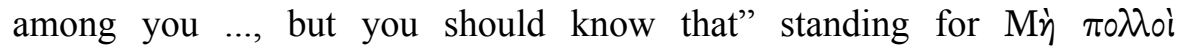

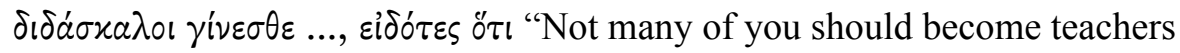
..., knowing that."

There are places where the translator used a subordinating conjunction instead. In Jas 1:13, for example, the source text undzis

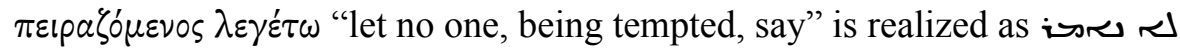
"let no one say when he is tempted," with the subordinating

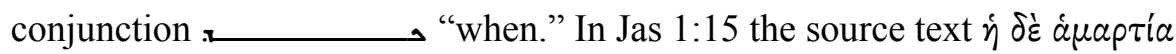

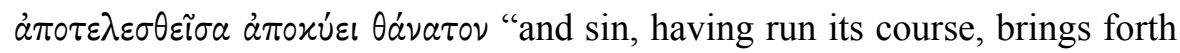

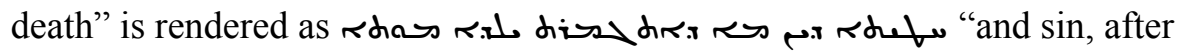
it has been brought to an end, brings forth death," with the subordinating conjunction $\longrightarrow$ "after." In Jas 2:21 the translator used $x$ as a temporal

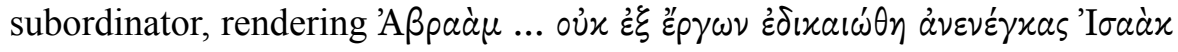

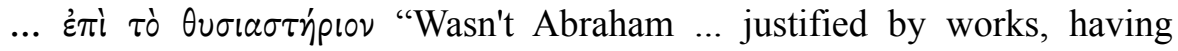




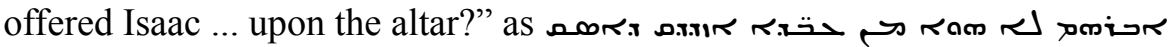
"Wasn't Abraham ... justified by works, when he offered Isaac ... upon the altar?"

\section{EXPRESSIONS IN IDIOMATIC SYRIAC}

The translator used idiomatic Syriac expressions in his translation. Lexemes consisting of two words in Syriac are used:

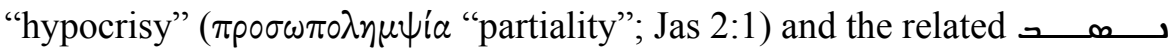

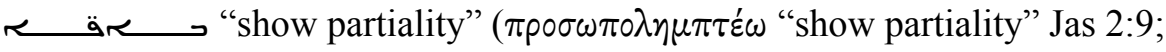

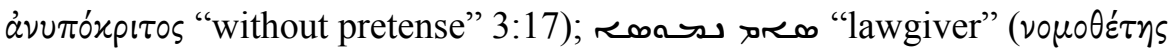
"lawgiver"; Jas 4:12 - the Syriac lexeme owes its origin to the Greek

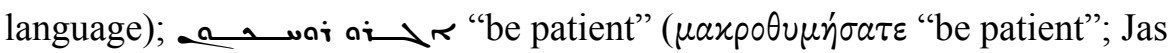

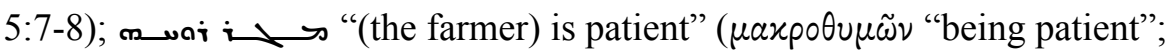

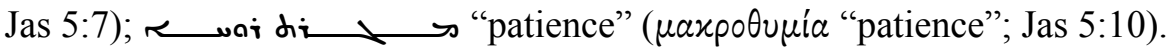
Moreover, the translator rendered "the same" expressed in Greek by the

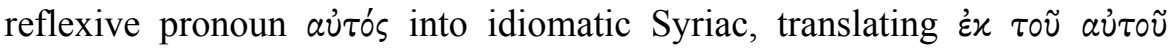

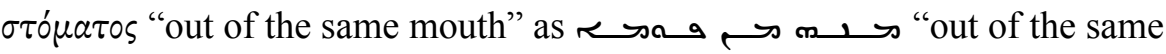
mouth" (Jas 3:10; preposition + proleptic pronoun - same preposition -

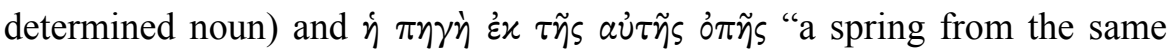
opening" as "from the same spring" (Jas 3:11; the numeral w "one" fronted before its nominal head).

With regard to the verb, the translator added the dative of reference:

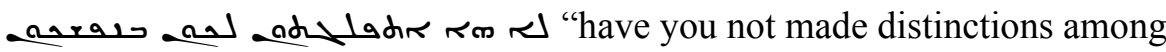

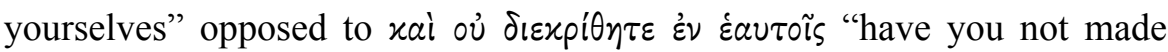
distinctions among yourselves" (Jas 2:4). He also added the ethical dative, a

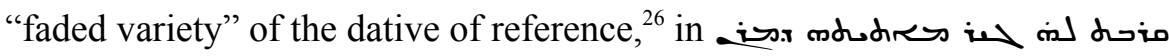

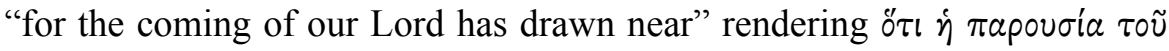

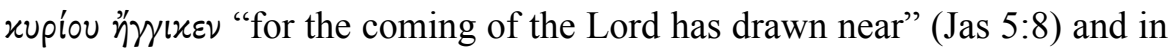
u sh "sit" translating xá 0 ou "sit" (Jas 2:3).

${ }^{26}$ J. B. Greenough et al. (eds.), Allen and Greenough's New Latin Grammar for Schools and Colleges (Boston: Ginn and Company, 1903), 236, § 380. 


\section{CLEAR INTERPRETIVE EXPRESSION IN THE TARGET LANGUAGE}

The translator transferred certain Greek expressions into idiomatic Syriac by exegeting them for the benefit of the reader. In Jas 1:1 the rendering "those scattered among the nations" explains the

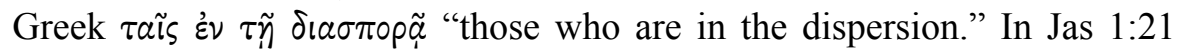
"the word that is implanted in our nature" interprets the

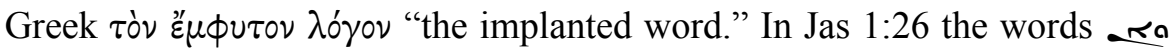
"and if anyone thinks that he serves God" translate

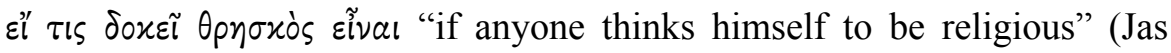

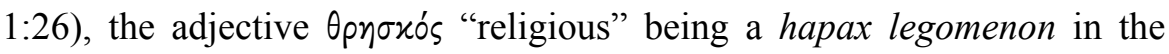

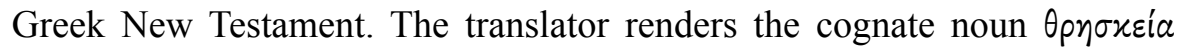
"worship" in this context similarly, using rdr_sed "service" (Jas 1:26-27).

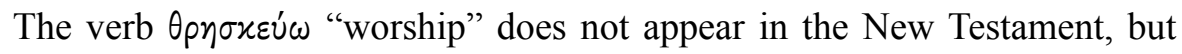
does in Wis 11:15, where the Syriac renders it with the verb "worship."

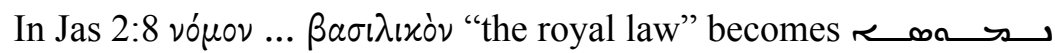
rm a "the law of God," making it clear that royal refers to the Deity. In Jas 2:4 the translator renders $x p ı \tau \alpha i \delta_{1} \alpha \lambda \circ \gamma\llcorner\sigma \mu \tilde{\omega} \nu \pi 0 \nu \eta \rho \tilde{\omega} \nu$ "judges of [with] evil thoughts" as sa "expounders ${ }^{27}$ of evil thoughts."

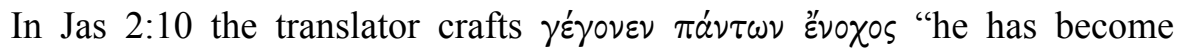
guilty of all" into لصلم she has become guilty of the whole law" for clarity. The translator changed the second person plural of the verb ó $\tilde{\tau} \tau \varepsilon$ ("you see" that ...) of Jas 2:24 into the singular (. ( the flow of the argument into line with the previous context (Jas 2:18-20). By adding prepositions in his translation of Jas 2:13 the translator brought

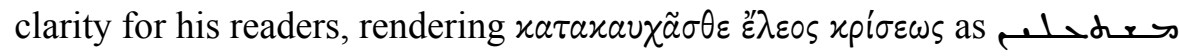

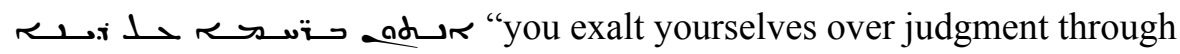

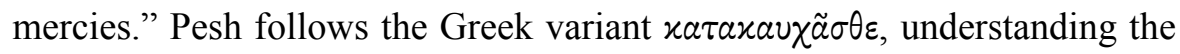
form ${ }^{\prime \prime} \lambda \varepsilon \circ \varsigma$, a neuter noun, to be in the accusative case, with the oblique

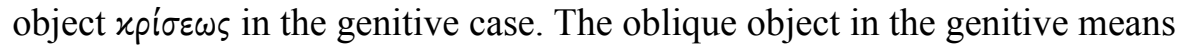

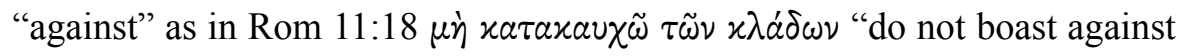
the branches," the Syriac translating "do not boast

${ }^{27}$ Sokoloff, A Syriac Lexicon, 811. 
against the branches." Pesh-Jas 2:5 offers an interesting exegesis of the Greek differing from English translations, at least. The Peshitta

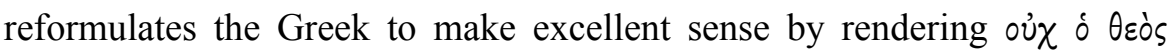

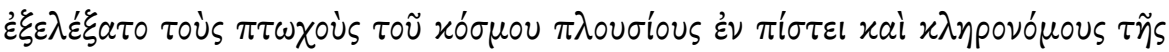

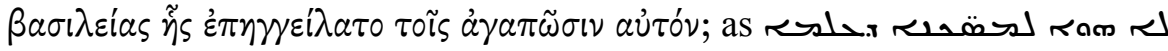

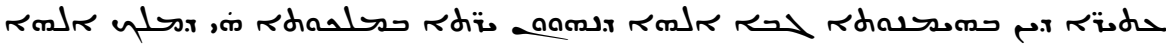
"Was it not the poor of the world, but rich in faith, that God chose that they should be heirs in the kingdom which God promised to those who love him?" Contrast NRSV: "Has not God chosen the poor in the world to be rich in faith and to be heirs of the kingdom that he has promised to those who love him?"

The translator transformed the conditional clause of the Greek into a

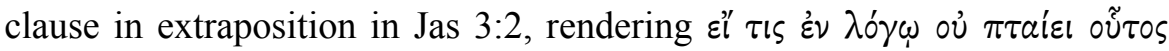

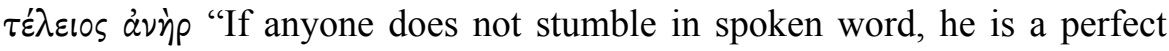
man" as "Everyone who does not stumble in spoken word, this one is a perfect man." In the same

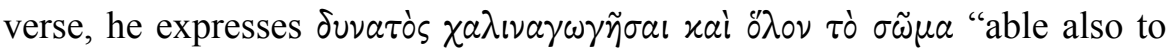
bridle the entire body" in fine Syriac as min "who is able also to subdue his entire body." The complement of the word "be able" appears as a prefix conjugation - not an infinitive as in the Greek attached asyndetically and the personal pronoun "his," implicit in the Greek, enters the translation.

In Jas 3:6 the translator reformulates the Greek and offers an interpretive translation for clarity. In the first part of the verse, the translator

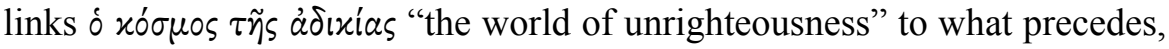
making it a second predicate linked by "and." In addition, the translator adds a comparative "like a forest," possibly from "forests" of the previous verse. The first part then reads as follows: am "And the tongue is a fire and a world of sin like a forest." In the second part of the verse, the Greek structure has the subject, $\dot{\eta} \gamma \lambda \tilde{\omega} \sigma \sigma \alpha$

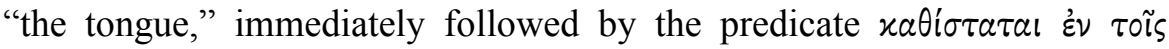

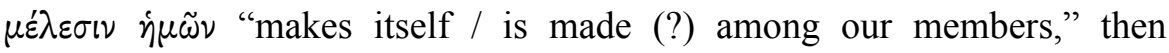
followed by a series of dependent clauses $\left(\dot{\eta} \sigma \pi i \lambda \circ \tilde{v} \sigma \alpha \ldots\right.$... xai $\phi \lambda \circ \gamma_{i}^{\prime} \zeta 0 v \sigma \alpha \ldots$

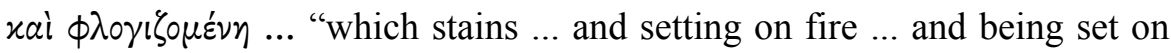
fire ..."). The Peshitta reformulates the Greek syntactically, having the 
subject ("the tongue") followed by a temporal clause ("when it is among the members") followed by the predicate (... "dofiles ... and sets ablaze ... and burns ..."). In addition, the translator offers the interpretive rendering "the successions

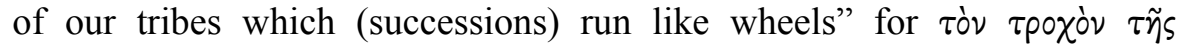
$\gamma \varepsilon \nu \varepsilon \dot{\sigma \varepsilon \omega \varsigma}$ "the wheel (course) of the family line." Moreover, he renders $\dot{\tau} \pi \dot{o}$

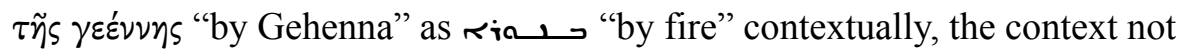
having to do with eternal judgment. To sum up, the translator attempted to make sense of the Greek in a clear way for his readers and hence paraphrases the Greek in this verse.

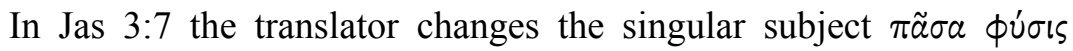

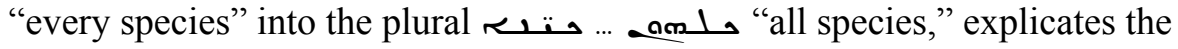

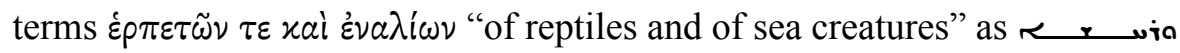
"ars creepers of the sea and of the dry land," and condenses the verbs $\delta a \mu \alpha \dot{\zeta} \varepsilon \tau a l$ xai $\delta \varepsilon \delta \dot{\alpha} \mu a \sigma \tau \alpha l$ "can be tamed and has been tamed" into

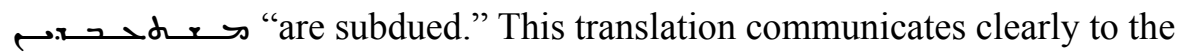
readers.

In Jas 4:6 the translator offers a reader friendly translation of $\delta \theta \varepsilon \dot{s}$

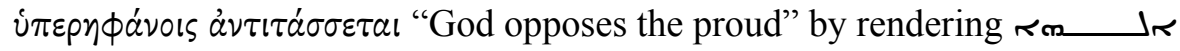
"God humbles the proud."

In Jas 5:13 the translator transforms the Greek into an easily understandable form by adding the conditional $\_$o "and if" and expressing the jussive by the paraphrasic construction, namely ram as jussive plus the

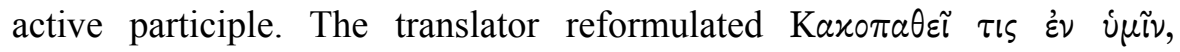

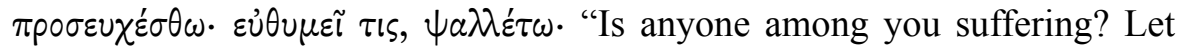

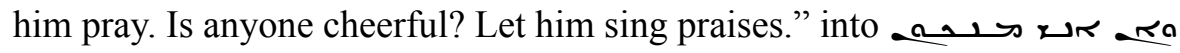
"And if anyone among you should be in distress, let him pray. And if anyone rejoices, let him

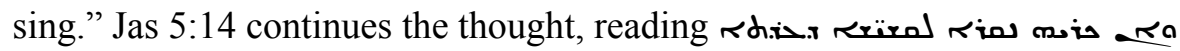
"And if sick, he should summon the elders of the congregation," reflecting

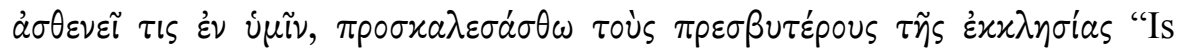
anyone among you sick? Let him summon the elders of the congregation." The translator again inserts 주 "and if," making the first clause conditional, and eliminates $\varepsilon \dot{\nu}$ ช́ $\mu \tilde{\nu}$ "among you" as redundant. 
In Jas 5:15, the translator rendered "the prayer of faith will save

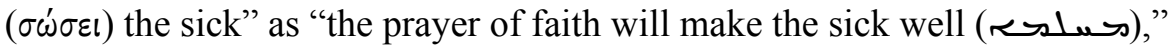
clearly expressing the meaning of the Greek. In keeping with good Syriac style, he used the proleptic pronoun on "to him," pointing forward to an

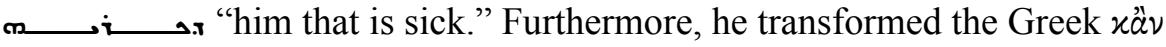

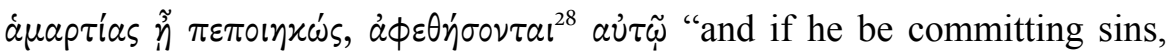
they shall be forgiven him" into clear Syriac by rendering r and if sins have been committed by him, they shall be forgiven him."

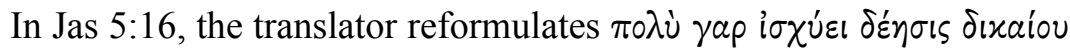

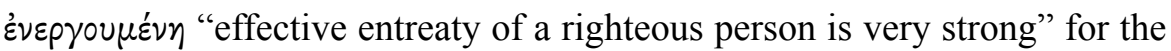

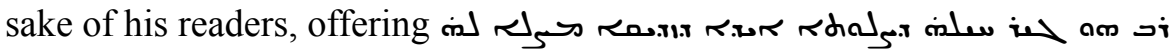
"for great is the power of the prayer that the righteous prays."

In Jas 5:19 the translator adds the words "from his error" for

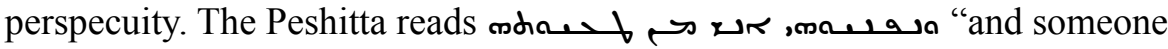

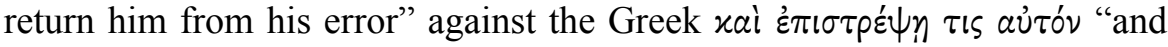
someone return him."

\section{CONCLUSION}

The translation features discussed above, found in the Peshitta Epistle of James, point clearly to a reader oriented translation. The translator uses idiomatic Syriac, transforming the Greek of his source text into clear Syriac expression. His was not a source text oriented translation.

\section{BIBLIOGRAPHY}

\section{TEXTS}

Das Neue Testament in syrischer Überlieferung, I: Die grossen katholischen Briefe. In Verbindung mit A. Juckel, herausgegeben und untersucht von Barbara Aland. ANTT 7. Berlin: de Gruyter, 1986.

${ }^{28}$ The Syriac reflects the plural $\dot{\phi} \varepsilon \theta \dot{\eta} \sigma o v \tau \alpha$ l against the singular $\dot{\phi} \phi \varepsilon \theta \dot{\eta} \sigma \varepsilon \tau \alpha l$. 
Novum Testamentum Graecum, Editio Critica Maior, IV: Catholic Letters. Part 1: Text and Part 2: Supplementary Material. Edited by The Institute for New Testament Textual Research. 2nd Revised Edition. Stuttgart: Deutsche Bibelgesellschaft, 2013.

Novum Testamentum Graece. Edited by Barbara and Kurt Aland, Johannes Karavidopoulos, Carlo M. Martini, and Bruce M. Metzger. 28th revised edition. Stuttgart: Deutsche Bibelgesellschaft, 2012. Accordance module NA28-T. Version 1.9.

Novum Testamentum Graece, Vol. 2. Edited by Constantinus Tischendorf. Editio octava critica maior. Leipzig: Giesecke \& Devrient, 1872.

The New Testament in Syriac. London: The British and Foreign Bible Society, [1920]. Accordance module PESHNT-T. Version 3.0.

\section{STUDIES}

Balzaretti Claudio. The Syriac Versions of Ezra-Nehemiah: Manuscripts and Editions, Translation Technique and Its Use in Textual Criticism. Translated by Michael Tait. Biblica et orientalia 51. Rome: Gregorian \& Biblical Press, 2013.

Brock Sebastian. The Bible in the Syriac Tradition. Second Revised Edition. Gorgias Handbooks 7. Piscataway: Gorgias Press, 2006.

Carbajosa Ignacio. The Character of the Syriac Version of Psalms, A Study of Psalms 90-150 in the Peshitta. Translated by Paul Stevenson. Monographs of the Peshitta Institute 17. Leiden: Brill, 2008.

Greenough J. B. et al. (eds.). Allen and Greenough's New Latin Grammar for Schools and Colleges. Boston: Ginn and Company, 1903.

Metzger Bruce M. (ed.). A Textual Commentary on the Greek New Testament. Second edition. Stuttgart: Deutsche Bibelgesellschaft, 1994.

Morrison Craig E. The Character of the Syriac Version of the First Book of Samuel. Monographs of the Peshitta Institute 11. Leiden: Brill, 2001.

Nöldeke Theodor. Compendious Syriac Grammar. Translated by James A. Crichton. London: Williams \& Norgate, 1904.

Pozzobon Mirko. La Peshitta del Secondo Libro di Samuele. Analecta Biblica 214. Rome: Gregorian \& Biblical Press, 2016.

Sokoloff Michael. A Syriac Lexicon. Winona Lake: Eisenbrauns and Piscataway: Gorgias Press, 2009.

Williams Peter J. Early Syriac Translation Technique and the Textual Criticism of the Greek Gospels. Texts and Studies III, 2. Piscataway: Gorgias Press, 2004. 